\title{
Evaluation of costs and outcomes associated with pharmacological thromboprophylaxis (unfractionated heparin and low molecular weight heparins) of venous thromboembolism at orthopedic ward in Clinical Hospital Stip
}

\author{
Biljana Lazarova $^{1 *}$, Aleksandra Kapedanovska Nestorovska ${ }^{2}, Z_{\text {Zoran Sterjev }}^{2}$, \\ Ljubica Suturkova ${ }^{2}$

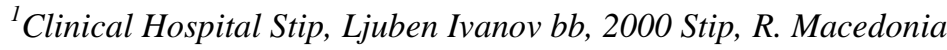 \\ ${ }^{2}$ Faculty of Pharmacy, Ss. Cyril and Methodius University, Majka Tereza 47, 1000 Skopje, R. Macedonia
}

Received: October 2017; Accepted: December 2017

\begin{abstract}
Clinical trials have shown Low-molecular weight heparins (LMWHs) to be at least as safe and efficacious as unfractionated heparin (UFH) for preventing venous thromboembolism (VTE) in patients undergoing major orthopedic surgery who are at highest risk of developing VTE. The retrospective study was conducted at orthopedic department in Clinical Hospital - Stip for period of 12 months (January-December 2013), where LMWHs and UFH are accepted thromboprophylaxis options. 320 patients (144 males and 157 females, medium age 58 years and 70 years, respectively) were hospitalized for various types of major orthopedic surgical interventions. 212 $(66 \%)$ patients were admitted because of hip or knee fractures, $26(8 \%)$ had conditions after hip or knee fractures and $82(26 \%)$ were hospitalized for removal or implanting of osteosynthetic devices. After the surgical intervention, patients were subjected to anticoagulant prophylaxis (UFH or LMWHs). Which type of prophylaxis will be used depended exclusively on the surgeon's decision. VTE complications resulting death were observed in $8(2.5 \%)$ out of 13 patients. Death because of PE occurred in $2(25 \%)$ out of 8 patients, compared to 6 (75\%) patients who had fatal DVT complications. The average hospital cost for patients treated with LMWHs prophylaxis as first line thromboprophylaxis option was $52831.92 \mathrm{MKD} /$ patient compared to $70082.24 \mathrm{MKD} /$ patient for UFH first line thromboprophylaxis option. We observed that LMWHs thromboprophylaxis, applied in recommended doses subcutaneously once a day, is potentially more effective and cost saving option compared to UFH and should be considered as pharmacological treatment of first choice for the prevention of VTE (DVT and PE) in patients recovering from major orthopedic surgery at the orthopedic department in Clinical Hospital Stip.
\end{abstract}

Keywords: Thromboprophylaxis, major orthopedic surgery, LMWHs, UFH

\section{Introduction}

Venous thromboembolism (VTE) is potentially serious vascular event which most often occurs as a result of surgery or trauma. The risk factors that contribute for the occurrence of this condition include previous VTE or family history of VTE, immobility, venous stasis or obstruction, obesity (BMI>30), age (>50 years), cancer, sepsis, chronic heart failure (NYHA III or IV), nephritic

\footnotetext{
*blazarova55@yahoo.com
} 
syndrome, pregnancy, as well as the first 3 months postpartum (Hyers et al., 1998). VTE has two main clinical manifestations. The most common is deep vein thrombosis (DVT), which usually occurs in the deep veins of calf and spreads proximally. The second, pulmonary embolism (PE) is much more serious and can be lifethreatening. The long-term consequences of VTE may be an increased risk of recurrence, including $\mathrm{PE}$, and chronic venous insufficiency (FVO) resulting in chronic pain, swelling and ulceration of the feet (Geerts et al., 2001). VTE can dramatically reduce the quality of life and can have a significant financial impact on the health system and the patient (Ginsberg et al., 2000).

Patients undergoing hip fracture surgery (HFS), total hip or knee replacement (THR and TKR), the most commonly performed orthopedic surgery whose frequency is increasing worldwide is, are at highest risk of developing VTE (Conduah and Lieberman, 2005; Weng and Fitzgerald, 2006). Without prophylaxis, DVT diagnosed with venography after hip replacement (THR) occurs in $45-57 \%$ of patients and in $40-84 \%$ after (TKR). The incidence of fatal PE after hip or knee replacement is between 0.2 and $0.7 \%$ (McGarry at al., 2006; Murray et al., 1996). There are various approaches in prophylaxis and management of VTE and its main clinical manifestations (DVT and PE). They include both nonpharmacological (External Pneumatic Compression-EPC and Intermittent Pneumatic Compression-IPC devices) and pharmacological prophylactic methods. According to the recommendations of the American College of Chest Physicians Evidence-Based Clinical Practice Guidelines (8th Edition) every hospital should develop a formal strategy that addresses the prevention of VTE. For patients undergoing elective hip or knee arthroplasty, first line pharmacological prophylaxis takes one of the following three anticoagulant agents into account: LMWHs, fondaparinux, or a vitamin $\mathrm{K}$ antagonist (VKA). For patients undergoing HFS, the recommendation is the routine use of fondaparinux, LMWHs, a VKA, or low dose UFH. The recommendation for that patients undergoing hip or knee arthroplasty or HFS is to receive thromboprophylaxis for a minimum 10 days; for hip arthroplasty and HFS, continuing thromboprophylaxis $>10$ days and up to 35 days. Recommendation for all major trauma and all spinal cord injury (SCI) patients is to receive thromboprophylaxis.

Despite clinical guidelines and recommendations (Geerts et al., 2008) which provide strong and unequivocal evidence and advocate that pharmacological agents anticoagulants after major orthopedic surgery reduce the frequency of symptomatic VTE, decreases the length of hospital stay (LOS) associated with possible VTE complications and, when administered at the appropriate time, rarely causes surgical bleeding, careful thromboprophylaxis is still used sub optimally (Caprini and Hyers, 2006). The optimal thromboprophylactic approach in high-risk patients is not controversial, but rather an indispensable measure. According to the literature data, the VTE prophylaxis is not universally practiced, even in patients without contraindications. The challenges facing clinicians is not only to identify patient at risk for thromboembolism, but also to choose the appropriate method (pharmacological or the nonpharmacological) and regimen of thromboprophylaxis while balancing the prophylactic benefits and the risks associated with bleeding complications. The optimal type and duration of pharmacological prophylaxis is also questionable and never been adequately determined. In that manner, guidelines emphasize that individual patient values may lead to different choices and benefits that do or do not outweigh risks, burden, and costs.

The aim of this study was to describe the current trends in pharmacological thromboprophylaxis with UFH and LMWHs after orthopedic surgery interventions in Clinical Hospital Stip and evaluate the associated treatment costs and outcomes (LOS in days, occurrence of DVT and PE).

\section{Material and methods}

\section{Patients and setting}

The study was conducted at orthopedic department in Clinical Hospital Stip, where LMWHs (Enoxaparin and Fraxiparin) and UFH are accepted thromboprophylaxis options. All patients, age over 18 years, consecutively admitted at Orthopedic department in the period of 12 months (January-December 2013) for orthopedic surgical intervention under general anesthesia after confirmed normal Doppler results on examination of the lower limbs and at risk for VTE based on the American College of Chest Physicians guidelines were included. After the surgical intervention, patients were subjected to anticoagulant prophylaxis (UFH or LMWHs), daily monitored for protocol compliance and clinically examined for signs and symptoms of DVT and PE in agreement with the Department Protocol for VTE surveillance. If such symptoms and signs appeared, bilateral phlebography and/or pulmonary angiography were performed. All thrombi located in or above the popliteal vein were defined as proximal DVT. During hospitalization, all the patients were also monitored daily for the occurrence of early hematoma, hematoma at the injection site, or both, as well as other manifestations of bleeding. The pharmacological thromboprophylaxis would be discontinued in case of hematoma on the wound that requires surgical revision, macroscopic hematuria, gastrointestinal bleeding, or bleeding that needs a blood transfusion. The pharmacological prophylactic choice (UFH or LMWHs) depended exclusively on the surgeon's decision. In case of drug shortage, the first line anticoagulant was the one currently available at the department. There was no clear preference in favor of any of anticoagulants and all of them are recommended by the 
Table 1. Protocol used for the VTE thromboprophilaxis at Clinical Hospital - Stip, Orthopedic ward

\begin{tabular}{lll}
\hline \hline Drug & $\begin{array}{l}\text { Thromboprophilaxis protocol } \\
\text { Preoperative }\end{array}$ & Postoperative \\
\hline UFH & $\begin{array}{l}\text {-The first dose of 5000 IU, given about 16 hours } \\
\text { before surgery } \\
\text {-Activated thromboplastin time, measured four hours } \\
\text { later, so that if needed, the next dose of heparin given } \\
\text { two hours before surgery, may be adjusted }\end{array}$ & $\begin{array}{l}\text {-Subsequent doses of } 5000 \text { IU administered } \\
\text { subcutaneous at an interval of 12 hours }\end{array}$ \\
LMWH & $\begin{array}{l}\text {-4000 IU Enoxaparin/ Fraxiparine, subcutaneously, } \\
12 \text { hours before surgery }\end{array}$ & $\begin{array}{l}-4000 \text { IU, 12 hours after surgery and then every } \\
\text { morning the following days during hospitalization } \\
\text { period }\end{array}$ \\
\hline
\end{tabular}

American College of Chest Physicians (ACCP) (Geerts et al., 2008). The treatment protocol used for the VTE tromboprophilaxis is described in Table 1.

\section{Unit costs}

Unit costs (Table 2) were taken from the official, publically available hospital and health care insurance data and included direct drug costs for VTE (DVT and PE) prophylaxis (UFH/10000 IU and LMWHs/4000 IU) and hospitalization costs (hospital full board, disposables, medical services, concomitant therapy, healthcare professional time).

\section{Statistical analysis}

Patient demographic and clinical characteristics were compared using Pearson's tests, Student's t tests, and Mann-Whitney rank tests, as appropriate. Fisher's exact tests were used when cell sizes contained less than five patients. Odds ratios [OR] were calculated with $95 \%$ confidence limits $[95 \%$ CI]. Statistically significant noninferiority was determined by comparing the $95 \%$ confidence intervals to the $10 \%$ margin of difference for the absolute risk difference between groups. Two-sided statistical significance was defined by $\mathrm{p}<0.05$.

\section{Results}

The retrospective study included total of 320 patients (144 males and 157 females, medium age 58 years and 70 years, respectively) hospitalized at the orthopedic ward in Clinical Hospital - Stip. Demographic characteristics concerning indication for hospitalization and type of pharmacological thromboprophylaxis of all patients are presented in Table 3.

Out of 320 patients hospitalized for various types of major orthopedic surgical interventions, 212 (66\%) patients were admitted because of hip or knee fractures, 26 (8\%) patients had conditions after hip or knee fractures and $82(26 \%)$ patients were hospitalized for removal or implanting of osteosynthetic implants for fixation of bone fragments. Total of $13(4.07 \%)$ out of 320 patients had VTE associated complications. PE was diagnosed in 5 (1.56\%) patients, while 8 (2.5\%) patients developed DVT.

Table 2. Unit costs used to evaluate the total costs per patient associated with pharmacological thromboprophylaxis option

\begin{tabular}{lc}
\hline \hline Unit & Average cost per day (MKD) \\
\hline Hospital day (Medical services, Hospital full board, Disposables) & 1168.67 \\
Concomitant therapy* & 185.61 \\
Health care time & \\
Nurse & 900 \\
Specialist & 2250 \\
Disposables associated with anticoagulant treatment & \\
LMWHs (4000 IU) & 0 \\
UFH (10000 IU) & 30 \\
LMWHs+UH** & 30 \\
Drug cost & \\
LMWHs (4000 IU) & 131.36 \\
UFH (10000 IU) & 83.96 \\
Combined prophylaxis**(++) & 119.51 \\
\hline
\end{tabular}

\footnotetext{
*antibiotics and analgetics

*average cost /day of one dose UH (10000IU) plus tree doses LMWH (4000 IU), according to practice
}

Макед. фарм. билт., 63 (1) 25 - 34 (2017) 
Table 3. Demographic characteristics of patients admitted at the orthopedic ward at the Clinical Hospital Stip for surgery intervention

\begin{tabular}{lll}
\hline \hline Patients $(\mathrm{N}=320)$ & & $\mathrm{n}(\%)$ \\
\hline Gender & Man & $144(45 \%)$ \\
& Women & $176(56 \%)$ \\
Age & Man & $58(95 \% \mathrm{CI}, 55.13-60.97)$ \\
& Women & $70(95 \% \mathrm{CI}, 68.14-72.58)$ \\
Indication for hospitalization & Hip or knee fractures & $212(66.25 \%)$ \\
& Status post fractura & $26(8.125 \%)$ \\
Type of tromboprophylaxis & Other interventions* & $82(25.625 \%)$ \\
Type of mono tromboprophylaxis & Mono & $280(87.5 \%)$ \\
& Combined & $40(12.5 \%)$ \\
Type of combined tromboprophylaxis & UFH & $151(53.9285 \%)$ \\
& LMWHs & $129(46.0715 \%)$ \\
& UFH/LMWHs & $22(55 \%)$ \\
& LMWHs/UFH & $18(45 \%)$ \\
& Stabile (no VTE) & $307(95.93 \%)$ \\
& VTE complications: & $13(4.07 \%)$ \\
Outcome & DVT & $8(2.5 \%)$ \\
& PE & $5(1.56 \%)$ \\
& Major bleeding & $0(0 \%)$ \\
& Dead & $8(2.5 \%)$ \\
& &
\end{tabular}

*osteosynthetic implants for fixation of bone fragments (bone plates, other fixation devices)

VTE complications resulting death were observed in 8 $(2.5 \%)$ out of 13 patients. Death because of PE occurred in $2(25 \%)$ out of 8 patients, compared to $6(75 \%)$ patients who had fatal DVT complications. Major bleeding as a possible side event was not observed in any of the hospitalized, thromboprofilacticaly treated patients. The average LOS for all 320 patients was 14.569 days ( $\mathrm{SD}=11.36 ; 95 \% \mathrm{CI}=13.31-15.82$ ). The average LOS for each subgroup of patients is shown in Table 4.

Patients treated with mono thromboprophylaxis (UHF or LMWHs) had significantly shorter LOS compared to those on combined thromboprophylaxis (UHF + LMWHs) (13.80 vs. 19.98; p=0.0015). Statistically significant difference was observed when we evaluated the average LOS of patients stratified according to type of mono thromboprophylaxis. Compared to LMWHs thromboprophylaxis, patients on UHF mono thromboprophylaxis had approximately 4 days longer LOS (15.56 vs. 11.73; $\mathrm{P}(\mathrm{Z} \leq \mathrm{z})$ two-tail=0.001375). No statistically significant difference in the average LOS was observed when comparing patient according to gender, indication for hospitalization and type of combined thromboprophilaxis protocol. As it is shown in Table 5, patient stratification to three subgroups according to the LOS (up to 11 days, 11-20 days, more than 20 days) showed that LMWHs thromboprophylaxis was associated with significantly shorter period of hospitalization compared to UFH thromboprophilaxis $(p=0.000012)$ and combined thromboprophylaxis $(\mathrm{p}=0.0015)$.
The average time of receiving anticoagulant prophylaxis was 11.024 days/patient for UFH compared to 8.244 days/patient of active anticoagulant prophylaxis with LMWHs. During this period of prophylaxis, total of 75065.79 IU/patient of UFH and 23142.64 IU/patient of LMWHs were used, resulting in utilization of average 6809.31 IU/patient/day for patients on UHF prophylaxis and 2808.23 IU /patient/day for those on LMWHs prophylaxis. The average IU/patient /day for combined thromboprophylaxis associated with time on anticoagulant prophylaxis /patient and average IU/ patient are shown in Table 6.

The associated average cost (MKD) per patient during time of hospitalization (LOS and anticoagulant prophylaxis) is presented in Table 7. The total cost of hospitalization for patients on UFH and LMWHs thromboprophylaxis was $71177.49 \mathrm{MKD} /$ patient and 53591.92 MKD/patient, respectively. The cost related with combined UFH/LMWHs prophylaxis was 96822.52 MKD/patient compared to $86248.11 \mathrm{MKD} /$ patient for LMWHs/UFH prophylaxis.

The associated average drug cost/patient for the first line UFH prophylaxis (mono thrombo prophylaxis and combined UFH/LMWHs) was significantly higher (1095.25 MKD and 1247.64 MKD, respectively) compared to cost/patient (760.00 MKD and 852.27 MKD) when using LMWHs (mono prophylaxis and combined LMWHs/UFH, respectively) as first line prophylactic option. The same trend was observed regarding 
Table 4. Average hospital LOS by gender, indications, type of thromboprophylaxis

\begin{tabular}{|c|c|c|c|}
\hline Patients & & $\begin{array}{l}\text { Average hospital length stay (SD; } \\
95 \% \mathrm{CI} \text { ) }\end{array}$ & $\mathrm{P}$ \\
\hline Gender & $\begin{array}{l}\text { Man } \\
\text { Women }\end{array}$ & $\begin{array}{l}14.5(13.47 ; 12.28-16.72) \\
14.6(9.33 ; 13.24-16.01) \\
13.302(7.25 ; 12.32-14.28)\end{array}$ & \multirow{4}{*}{$\begin{array}{c}\text { (KW test) } 0.00154 \\
\text { ( } \mathrm{z} \text { test, } \mathrm{t}-\text { test, two } \\
\text { sided) } \\
0.001375 \\
>0.05\end{array}$} \\
\hline $\begin{array}{l}\text { Indication for } \\
\text { hospitalization }\end{array}$ & $\begin{array}{l}\text { Hip or knee fractures } \\
\text { Status post fractura } \\
\text { Other interventions* }\end{array}$ & $\begin{array}{l}14.192(12.77 ; 9.04-19.35) \\
17.963(17.48 ; 14.12-21.80)\end{array}$ & \\
\hline Type of thromboprophylaxis & $\begin{array}{l}\text { Mono } \\
\text { Combined }\end{array}$ & $\begin{array}{l}13.80(10.44 ; 12.57-15.03) \\
19.98(15.55 ; 15.00-24.95)\end{array}$ & \\
\hline $\begin{array}{l}\text { Type of mono } \\
\text { thromboprophylaxis }\end{array}$ & $\begin{array}{l}\text { UFH } \\
\text { LMWHs }\end{array}$ & $\begin{array}{l}15.56(11.84 ; 13.66-17.46) \\
11.73(8.10 ; 10.32-13.14)\end{array}$ & \\
\hline $\begin{array}{l}\text { Type of combined } \\
\text { thromboprophylaxis }\end{array}$ & $\begin{array}{l}\text { UFH/LMWHs* } \\
\text { LMWHs/UFH** }\end{array}$ & $\begin{array}{l}21.22(17.14 ; 12.70-29.75) \\
18.96(14.44 ; 12.55-25.36)\end{array}$ & \\
\hline
\end{tabular}

cost associated with hospital stay. The average hospital cost for patients treated with LMWHs prophylaxis as first line treatment option was $52831.92 \mathrm{MKD} /$ patient compared to $70082.24 \mathrm{MKD} /$ patient for UFH first line prophylactic strategy.

Total cost/ patient associated with combined thromboprophylaxis (183070.63 MKD) was significantly higher compared to the total costs of mono thromboprophylaxis strategy (124769.41 MKD) (Table 7).

The total costs for treating all 320 patients hospitalized at the Clinical Hospital Stip for orthopedic surgery intervention, according to the type of tromboprophylaxis are shown in Table 8.

\section{Discussion}

Venous thromboembolism (VTE) is a common complication in patients undergoing orthopedic surgery and has important clinical consequences, including deep vein thrombosis (DVT), pulmonary embolism (PE), increased length of stay in the intensive care unit (ICU) and hospital and death (Geerts et al., 2001; Ginsberg et al., 2000; Hyers et al., 1998). The rates of VTE complications such as DVT and PE have been shown to be around $40-60 \%$ within 7 to 14 days following orthopaedic surgery without thromboprophylaxis
(Geerts et al., 2004; Geerts et al., 2008). Most of these thrombi resolve spontaneously; however, a small percentage (1-4\%) will develop into symptomatic VTE (Kim et al., 2003). The incidence of fatal pulmonary embolisms in patients not receiving thromboprophylaxis ranges from $0.3-1 \%$ following total joint arthroplasty (TJA) and around 3.6\% after hip fracture surgery (HFS) (Stringer et al., 1989). Although DVT has potentially serious consequences, it is often unrecognized in the ICU as the clinical examination for DVT lacks sensitivity and specificity (Conduah and Lieberman, 2005; Weng et al., 2005). Further, routine ultrasound screening for DVT is not a cost-effective diagnostic strategy in practice (Weng et al., 2005). A proactive approach to reduce the incidence of VTE is therefore of paramount importance. Thus, thromboprophylaxis is the most appropriate mechanism to prevent VTE and its complications among this population of patients. (Fowler et al., 2014).

UFH and LMWHs have been prescribed for orthopaedic thromboprophylaxis for decades. LMWHs had largely replaced UFH due to the fact that no monitoring is required and to its simple mode of administration via subcutaneous injection. Many studies have shown fewer VTEs and less bleeding complications with LMWHs compared with UFH in orthopaedic surgery (Nurmohamed et al., 1992; Palmer et al.,1997). One must be aware, however, of the potential for delayed fracture healing, thrombocytopenia, and osteoporosis with the 
Table 5. Length of stay according to type of thromboprophylaxis

\begin{tabular}{|c|c|c|c|c|c|}
\hline \multirow{2}{*}{\multicolumn{2}{|c|}{$\begin{array}{l}\text { Type of } \\
\text { tromboprophylaxis }\end{array}$}} & \multicolumn{3}{|c|}{ Length of stay $-\mathrm{n}(\%)$} & \multirow{2}{*}{$\mathrm{X}^{2} ; \mathrm{p}$} \\
\hline & & Up to 11 days & $11-20$ days & more than 20 days & \\
\hline \multirow{2}{*}{ Mono } & UFH & $58(31 \%)$ & $64(42 \%)$ & $29(19 \%)$ & \multirow{2}{*}{$22.62 ; 0.000012$} \\
\hline & LMWHs & $86(67 \%)$ & $32(25 \%)$ & $11(8 \%)$ & \\
\hline \multicolumn{2}{|c|}{ Combined } & $14(35 \%)$ & $18(45 \%)$ & $8(20 \%)$ & $\begin{array}{l}\text { vs. } \mathrm{UFH}=0.16 ; 0.92 \\
\text { vs. } \mathrm{LMWHs}=12.96 \text {; } \\
0.0015\end{array}$ \\
\hline
\end{tabular}

extended use of UFH and, to a lesser extent, LMWHs, though the benefit of overall VTE risk reduction does appear to justify these risks (Ahmed et al., 2007; Handschin et al., 2005; Street et al., 2000). The current guidelines from the American Academy of Orthopaedic Surgeons (AAOS) and the American College of Chest Physicians (AACP) for patients undergoing total hip arthroplasty (THA) or total knee arthroplasty (TKA), recommend use of low-molecular-weight heparin (LMWH), fondaparinux, apixaban, dabigatran, rivaroxaban, low-dose unfractionated heparin (LDUH), adjusted-dose vitamin $\mathrm{K}$ antagonist (VKA), aspirin or an intermittent pneumatic compression device (IPCD) for a minimum of 10 to 14 days rather than no antithrombotic prophylaxis. In patients undergoing hip fracture surgery (HFS), use of one of the following rather than no antithrombotic prophylaxis for a minimum of 10 to 14 days is recommended: LMWH, fondaparinux, LDUH, adjusted-dose VKA, aspirin, or an IPCD. For patients undergoing major orthopedic surgery (THA, TKA, HFS) and receiving LMWH as thromboprophylaxis, AAOS and AACP recommend starting either $12 \mathrm{~h}$ or more preoperatively or $12 \mathrm{~h}$ or more postoperatively rather than within $4 \mathrm{~h}$ or less preoperatively or $4 \mathrm{~h}$ or less postoperatively (Falck-Ytter et al., 2012; Mont et al., 2011).

The pharmacological tromboprophylaxis protocol at the orthopedic department in Clinical Hospital Stip used subcutaneous low doses UFH and LMWHs as pharmacological prophylaxis is in accordance with the accepted recommendations from AACP evidence-based clinical practice guidelines (8th edition). All 320 patients who had orthopedic surgical interventions were analyzed in terms of the presence of risk factors for developing VTE (average age, type of intervention, and post-operative immobility) and it was determined that the total score of risk factors is 2-5 (moderate to highest), and therefore all patients, according to the recommendations, were subjected to thromboprophylaxis.

A total of 280 patients $(87.5 \%)$ underwent a mono thromboprophylaxis with UFH or LMWHs, while 40 patients $(12.5 \%)$ received combined thromboprophylaxis of UFH and LMWHs in the period when the hospital pharmacy had a lack of one or other anticoagulant, so if the surgeon had ordered UFH and it was not available at stock in the pharmacy, prophylaxis had begun with LMWHs and

Table 6. Average time on anticoagulant prophylaxis and average IU/ patient/day

\begin{tabular}{|c|c|c|c|c|}
\hline \multicolumn{2}{|c|}{ Type of tromboprophylaxis } & $\begin{array}{c}\text { Average time on } \\
\text { anticoagulant } \\
\text { prophylaxis/patient (days) } \\
\text { Mean } \\
\text { (SE; 95\%CI) } \\
\end{array}$ & $\begin{array}{l}\text { Average IU/ patient } \\
\text { Mean (SE; 95\%CI) }\end{array}$ & $\begin{array}{l}\text { Average IU/ } \\
\text { patient/day }\end{array}$ \\
\hline \multirow{2}{*}{ Mono } & UFH & $\begin{array}{c}11.024 \\
(7.99 ; 9.61-12.44)\end{array}$ & $\begin{array}{c}75065.79 \\
(5941.357 ; 63326.86-86804.72)\end{array}$ & 6809.31 \\
\hline & LMWHs & $\begin{array}{c}8.241 \\
(6.27 ; 7.20-9.30)\end{array}$ & $\begin{array}{c}23142.64 \\
(2812.239 ; 17578.15-28707.16)\end{array}$ & 2808.23 \\
\hline \multirow[t]{2}{*}{ Combil } & $\begin{array}{l}\text { UFH/LMWH } \\
\text { s }\end{array}$ & $\begin{array}{c}9.438 \\
(5.97 ; 6.26-12.62)\end{array}$ & $\begin{array}{c}72777.78 \\
(83933.14 ; 31038.81-114516.74)\end{array}$ & 7711.14 \\
\hline & $\begin{array}{l}\text { LMWH/UFH } \\
\text { s }\end{array}$ & $\begin{array}{c}8.933 \\
(8.38 ; 4.29-13.57)\end{array}$ & $\begin{array}{c}25952.27 \\
(33779.8 ; 10975.15-40929.40)\end{array}$ & 2905.21 \\
\hline
\end{tabular}


Table 7. Average cost (MKD) per patient during time of hospitalization

\begin{tabular}{|c|c|c|c|c|}
\hline & & \multicolumn{3}{|c|}{ Average cost (MKD) per patient during time of hospitalization } \\
\hline \multicolumn{2}{|c|}{ Type of tromboprophylaxis } & Hospital stay* & $\begin{array}{l}\text { Anticoagulant } \\
\text { treatment/IU** }\end{array}$ & Total \\
\hline Mono & $\begin{array}{l}\text { UFH } \\
\text { LMWH }\end{array}$ & $\begin{array}{l}70082.24 \\
52831.92\end{array}$ & $\begin{array}{c}1095.25 \\
760.0043\end{array}$ & $\begin{array}{l}71177.49 \\
53591.92\end{array}$ \\
\hline Combined & $\begin{array}{l}\text { UFH/LMWH } \\
\text { LMWH/UFH }\end{array}$ & $\begin{array}{l}95574.88 \\
85395.84\end{array}$ & $\begin{array}{c}1247.64 \\
852.2725\end{array}$ & $\begin{array}{l}96822.52 \\
86248.11\end{array}$ \\
\hline Total & & 303884.90 & 3955.16 & 307840.0 \\
\hline
\end{tabular}

mono thromboprophylaxis with UFH or LMWHs, while 40 patients $(12.5 \%)$ received combined thromboprophylaxis of UFH and LMWHs in the period when the hospital pharmacy had a lack of one or other anticoagulant, so if the surgeon had ordered UFH and it was not available at stock in the pharmacy, prophylaxis had begun with LMWHs and then was continued with UFH when it would become available and vice versa. Clinical trials conducted among medical inpatients have shown thromboprophylaxis with LMWH to be at least as safe and efficacious as UFH in this population, and LMWH may offer clinical advantages over UFH, including longer duration of action, more predictable response, and once-daily subcutaneous administration (Conduah et al., 2005; Ginsberg et al., 2000; McGarry et al., 2006; Murray et al., 1996; Weng et al., 2006). The outcome results showed that administered thromboprophylaxis was clinically effective and 307 patients were stabile without signs and symptoms for VTE. Only 13 out of 320 patients got thromboembolic complications and 8 of them terminated with death. The rates of DVT and/or PE complications we observed are considerably lower compared to published data, primarily due to our decision to base results on the rates of symptomatic complications actually treated in clinical practice and not on the rates of potentially asymptomatic complications detected in clinical trials. According to our observations, low doses UFH failed to protect the orthopedic patients who had surgeries from DVT and PE since 10 out of 13 patients with complications were on UFH and 8 of the ended lethally. This observation collaborates the findings that LMWHs are more effective in preventing such thromboembolic events and is consistent with the results from the studies for embedment of artificial hip and knee (Geerts et al., 2004; Kim et al., 2003).

In case of major orthopedic surgery interventions, the Макед. фарм. билт., 63 (1) 25 - 34 (2017) average length of stay (LOS) is used as an indicator of treatment efficiency but also as an indicator for increased risk of outpatient death. Although shorter hospital stay reduces the cost per admission and aims to move patient care to less expensive community or rehabilitation settings, LOS less than 10 days, following especially hip fracture is associated with increased risk of death after discharge (Nordström et al., 2015). Our evaluation showed that the average LOS of all patients is approximately 14 days which minimizes the outpatient risk of death. Still, the comparison of LOS between patients receiving different type of pharmacological tromboprophylaxis (mono versus combined and LMWH versus UFH) in realworld clinical practice yielded results more favorable for mono thromboprophylaxis with LMWHs. Patients on combined thromboprophylaxis had 6 days longer length of stay compared to patients on mono thromboprophylaxis and patients on mono thromboprophylaxis with LMWH have statistically significant shorter LOS of 3.5 days compared to UFH treatment. Patient stratification in three subgroups according to LOS (up to 11 days, 11-20 days, more than 20 days) confirmed the findings that LMWHs thromboprophylaxis was associated with significantly shorter LOS compared to UFH thromboprophylaxis and combined thromboprophylaxis. This findings are consistent with the guidelines recommendations where the combinated thromboprophylaxis is not clinically justified primarily due to the different mechanism of action (UFH inactivates factor IIa (thrombin) and Xa, while LMWHs has bigger effect on factor Xa than factor IIa). The relationship between LMWHs prophylaxis and reduced length of stay can be explained with the more rapid onset of action and decrease in laboratory monitoring requirements for patients receiving LMWHs prophylaxis (Kearon et al., 2006). As a result, we observed that this treatment strategy reduces the hospital and treatment associated costs. Our analysis did not include any resource 
Table 8. Total costs for patients at Orthopedic ward in Clinical Hospital Stip admitted for orthopedic surgery intervention

Average costs for all patients $(\mathrm{N}=320)$ hospitalized at the Clinical Hospital - Stip for orthopedic surgery intervention

\begin{tabular}{|c|c|c|c|c|c|}
\hline \multicolumn{3}{|c|}{ Type of thromboprophylaxis (n) } & \multirow{2}{*}{$\begin{array}{c}\text { Hospital stay } \\
\\
10582418.24 \\
6815317.68\end{array}$} & \multirow{2}{*}{$\begin{array}{c}\begin{array}{c}\text { Anticoagulant } \\
\text { treatment }\end{array} \\
\\
165382.75 \\
98040.55\end{array}$} & \multirow{2}{*}{ 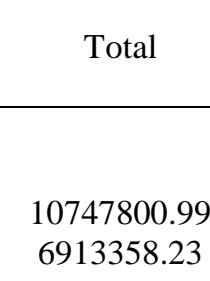 } \\
\hline $\begin{array}{c}\text { Type of mono } \\
\text { thromboprophylaxis }\end{array}$ & $\begin{array}{c}\text { UFH } \\
\text { LMWHs }\end{array}$ & $\begin{array}{l}151 \\
129\end{array}$ & & & \\
\hline $\begin{array}{l}\text { Type of combined } \\
\text { thromboprophylaxis }\end{array}$ & $\begin{array}{l}\text { UFH/LMWHs } \\
\text { LMWHs/UFH }\end{array}$ & $\begin{array}{l}22 \\
18\end{array}$ & $\begin{array}{l}2102647.36 \\
1537125.12\end{array}$ & $\begin{array}{l}27448.08 \\
15340.91\end{array}$ & $\begin{array}{l}2130095.44 \\
1552466.03\end{array}$ \\
\hline Total & & 320 & 21037508.40 & 306212.29 & 21343720.69 \\
\hline
\end{tabular}

costs other than those actually evidenced by patient data and was focused only on the costs of hospitalization. Taking this into consideration, the average cost per patient during hospitalization (hospital stay, health professional time and anticoagulant drug) for patients on combined thromboprophylaxis was significantly higher than total cost for monoprophylaxis strategy and monoprophylaxis strategy with UFH was significantly higher than total cost for monoprophylaxis strategy with LMWHs. The reduced patient monitoring requirements and avoided drug interaction problems with LMWHs treatment undoubtedly lead to more efficient use of medical staff. Despite the higher direct cost associated with the drug price of LMWHs compared to UFH in our country, LMWHs treatment strategy reduces the total cost of hospital stay to a greater extent which indicates that VTE prevention with LMWH as a first choice would contribute to significant hospital savings. The optimal duration of prophylaxis in these patients is not known, but our data suggest that should be continued at least until they are discharge from the hospital.

All our findings are in line with the published data indicating that LMWHs are an attractive alternative to UFH for prophylaxis of DVT and PE because of the reduced risk for complications or bleeding, simple method of application, ease of dosing no INR monitoring necessities and cost saving opportunities (Colwell et al., 1994; Colwell et al., 1995; Geerts et al., 2008). According to the evidence based data evaluating the total cost of care for events occurring in-hospital, no-prophylaxis and treatafter-diagnosis strategies (among the considered -no prophylaxis, selective treatment of DVT only after it was diagnosed, and routine prophylaxis in all patients with low-dose UFH and various LMWH products), are pointed to be the most costly with routine prophylaxis shown to be least expensive and LMWHs somewhat less costly strategy than low-dose UFH treatment (Forster and Stewart, 2016) The performed cost analysis was incomplete since several variables, (including the cost of mortality, post-thrombotic complications such as venous insufficiency, and the possibility that patients on the LMWHs regimen could have been treated outside of the hospital for part of the time) were ignored. Had they been considered, these factors might further favor the LMWH strategy over the others, including low-dose UFH (Bergqvist et al., 1996). Additional studies will provide more important information about the cost - effectiveness of treatment with LMWHs in our country.

\section{Conclusion}

Our study indicates that combined tromboprophilaxis is unjustified and contributes to increasing the cost of the hospital stay. Mono LMWHs therapy, applied in recommended doses subcutaneously once a day, is potentially more effective and cost saving option compared to UFH and should be considered as pharmacological treatment of first choice for the prevention of VTE (DVT and $\mathrm{PE}$ ) in patients recovering from major orthopedic surgery at the orthopedic ward in Clinical Hospital Stip.

Maced. pharm. bull., 63 (1) 25 - 34 (2017) 


\section{References}

Ahmed, I., Majeed, A., Powell, R., 2007. Heparin induced thrombocytopenia: diagnosis and management update. Postgrad. Med. J. 83(983), 575-582. Available at: https://doi.org/10.1136/pgmj.2007.059188.

Bergqvist, D., Lindgren, B., Mätzsch, T., 1996. Comparison of the cost of preventing postoperative deep vein thrombosis with either unfractionated or low molecular weight heparin. Br. J. Surg. 83, 1548-1552. Available at: https://doi.org/10.1002/bjs.1800831117.

Caprini, J.A., Hyers, T.M., 2006. Compliance with antithrombotic guidelines. Managed Care 15(9), 49-66.

Colwell Jr, C.W., Spiro, T.E., Trowbridge, A.A., Stephens, J.W., Gardiner Jr, G.A., Ritter, M.A., 1995. Efficacy and safety of enoxaparin versus unfractionated heparin for prevention of deep venous thrombosis after elective knee arthroplasty. Enoxaparin Clinical Trial Group. Clin. Orthop. 321, 19-27.

Colwell, C.W. Jr, Spiro T.E., Trowbridge A.A., et al., 1994. Use of enoxaparin, a lowmolecular-weight heparin, and unfractionated heparin for the prevention of deep venous thrombosis after elective hip replacement. A clinical trial comparing efficacy and safety. Enoxaparin Clinical Trial Group. J. Bone Joint Surg. Am. 76(1), 3-14. Available at: https://doi.org/10.2106/00004623-199401000-00002.

Conduah, A., Lieberman, J.R., 2005. Venous thromboembolic prophylaxis after elective total hip arthroplasty. Clin. Orthop. Relat. Res. 441, 274-84. Available at: https://doi.org/10.5371/hp.2018.30.4.197.

Falck-Ytter, Y., Francis, C.W., Johanson, N.A., Curley, C., Dahl, O.E., Schulman, S. et al., 2012. Prevention of VTE in orthopedic surgery patients: antithrombotic therapy and prevention of thrombosis, 9th ed: American College of Chest Physicians Evidence-Based Clinical Practice Guidelines. Chest 141(2 Suppl), e278S-325S. Available at: https://doi.org/10.1378/chest.11-2404.

Forster, R., Stewart, M., 2016. Anticoagulants (extended duration) for prevention of venous thromboembolism following total hip or knee replacement or hip fracture repair. Review Editorial Group: Cochrane Vascular Group. Available at: https://doi.org/10.1002/14651858.

Fowler, R.A., Mittmann, N., Geerts, W.H., Heels-Ansdell, D., Gould, M.K., Guyatt, G., Krahn, M., Finfer, S., Pinto, R., Chan, B., Ormanidhi, O., Arabi, Y., Qushmaq, I., Rocha, M.G., Dodek, P.,McIntyre, L., Hall, R., Ferguson, N.D., Mehta, S., Marshall, J.C., Doig, C.J., Muscedere, J., Jacka, M.J., Klinger, J.R., Vlahakis, N., Orford, N., Seppelt, I., Skrobik, Y.K., Sud, S., Cade, J.F., Cooper, J., Cook, D., 2014. Canadian Critical Care Trials Group; Australia and New Zealand Intensive Care Society Clinical Trials Group. Economic evaluation of the prophylaxis for thromboembolism in critical care trial (E-PROTECT): study protocol for a randomized controlled trial. Trials 15 , 502. Available at: https://doi.org/10.1186/1745-6215-15502.

Geerts, W.H., Bergqvist, D., Pineo, G.F., Heit, J.A., Samama, C.M., Lassen, M.R., Colwell, C.W., 2008. Prevention of venous thromboembolism: American College of Chest Physicians evidence-based clinical practice guidelines (8th edition). Chest 133(6), 381S-453S. Available at: https://doi.org/10.1378/chest.08-0656.

Geerts, W.H., Heit, J.A., Clagett, G.P., Pineo, G.F., Colwell,
C.W., Anderson Jr, F.A., Wheeler, H.B., 2001. Prevention of venous thromboembolism. Chest 119(1), 132S-175S.

Geerts, W.H., Pineo, G.F., Heit, J.A., Bergqvist, D., Lassen, M.R., Colwell, C.W. Ray, J.G., 2004. Prevention of venous thromboembolism: The Seventh ACCP Conference on Antithrombotic and Thrombolytic Therapy. Chest 126(3 Suppl), 338S-400S. Available at: https://doi.org/10.1378/chest.126.3_suppl.338S.

Ginsberg, J.S., Turkstra, F., Buller, H.R., MacKinnon, B., Magier, D., Hirsh, J., 2000. Postthrombotic syndrome after hip or knee arthroplasty: a cross-sectional study. Arch. Intern. Med. 160(5), 669-672. Available at: https://doi.org/10.1001/archinte.160.5.669.

Handschin, A.E., Trentz, O.A., Hoerstrup, S.P., Kock, H.J., Wanner, G.A., Trentz, O., 2005. Effect of low molecular weight heparin (dalteparin) and fondaparinux (Arixtra) on human osteoblasts in vitro. Br. J. Surg. 92(2), 177-183. Available at: https://doi.org/10.1002/bjs.4809.

Hyers, T.M., Agnelli, G., Hull, R.D., Weg, J.G., Morris, T.A., Samama, M., Tapson, V., 1998. Antithrombotic therapy for venous thromboembolic disease. Chest 114(5), 561S-578. Available at: https://doi.org/10.1378/chest.114.5_Supplement.561S.

Kearon, C., Ginsberg, J.S., Julian, M.A. et al., 2006. Comparison of fixed-dose weight-adjusted unfractionated heparin and low-molecular-weight heparin for acute treatment of venous thromboembolism. JAMA 296, 935-942. Available at: https://doi.org/10.1001/jama.296.8.935.

Kim, Y.H., Oh, S.H., Kim, J.S., 2003. Incidence and natural history of deep-vein thrombosis after total hip arthroplasty. A prospective and randomised clinical study. J. Bone Joint Surg. Br. 85(5), 661-665.

McGarry, L.J., Stokes, M.E., Thompson, D., 2006. Outcomes of thromboprophylaxis with enoxaparin vs. unfractionated heparin in medical inpatients. Thrombosis Journal 4, 17. Available at: https://doi.org/10.1186/1477-9560-4-17.

Mont, M.A., Jacobs, J.J.,2011. AAOS clinical practice guideline: preventing venous thromboembolic disease in patients undergoing elective hip and knee arthroplasty. J. Am. Acad. Orthop. Surg. 12, 777-778. Available at: https://doi.org/10.5435/00124635-201112000-00008.

Murray, D.W., Britton, A.R., Bulstrode, C.J., 1996. Thromboprophylaxis and death after total hip replacement. J. Bone Joint Surg. Br. 78(6), 863-870. Available at: https://doi.org/10.1302/0301-620x78b6.6714.

Nordström, P., Gustafson, Y., Michaëlsson, K., Nordström, A., 2015. Length of hospital stay after hipfracture and short term riskof death after discharge: a total cohort study in Sweden. British Medical Journal 350, h696. Available at: https://doi.org/10.1136/bmj.h696.

Nurmohamed, M.T., Rosendaal, F.R., Büller, H.R., Dekker, E., Hommes, D.W., Vandenbroucke, J.P. et al., 1992. Lowmolecular-weight heparin versus standard heparin in general and orthopaedic surgery: a meta-analysis. Lancet 340(8812), 152-156. Available at: https://doi.org/10.1016/0140-6736(92)93223-a.

Palmer, A.J., Koppenhagen, K., Kirchhof, B., Weber, U., Bergemann, R., 1997. Efficacy and safety of low molecular weight heparin, unfractionated heparin and warfarin for thrombo-embolism prophylaxis in orthopaedic surgery: a meta-analysis of randomised clinical trials. Haemostasis 27(2), 75-84. Available at: https://doi.org/10.1159/000217437.

Макед. фарм. билт., 63 (1) 25 - 34 (2017) 
Street, J.T., McGrath, M., O'Regan, K., Wakai, A., McGuinness, A., Redmond, H.P., 2000. Thromboprophylaxis using a low molecular weight heparin delays fracture repair. Clin. Orthop. Relat. Res. 381, 278289. Available at: https://doi.org/10.1097/00003086200012000-00032.

Stringer, M.D., Steadman, C.A., Hedges, A.R., Thomas, E.M.,
Morley, T.R., Kakkar, V.V., 1989. Deep vein thrombosis after elective knee surgery. An incidence study in 312 patients. J. Bone Joint Surg. Br. 71(3), 492-497.

Weng, H.H., Fitzgerald, J., 2006. Current issues in joint replacement surgery. Curr. Opin. Rheumatol. 18, 163-16. Available at: https://doi.org/10.1097/01.bor.0000209428.69528.96.

\title{
Евалуација на трошоците и резултатите поврзани со фармаколошката тромбопрофилакса (нефракциониран хепарин и хепарини со мала молекулска тежина) од венски тромбоемболизам на ортопедското одделение во Клиничка болница Штип
}

\author{
Биљана Лазарова ${ }^{1}$, Александра Капедановска Несторовска ${ }^{2}$, \\ Зоран Стерјев ${ }^{2}$, Љубица Шутуркова ${ }^{2}$ \\ ${ }^{1}$ Клиничка Болница Штип, Љубен Иванов бб, 200 Штип, Република Македонија \\ ${ }^{2}$ Фармацевтски факултет, Универзитет „Св. Кирил и Методиј”, Мајка Тереза 47, \\ 1000 Скопје, Република Македонија
}

\begin{abstract}
Клучни зборови: Тромбопрофилакса, големи ортопедски операции, хепарини со мала молекулска тежина, нефракциониран
\end{abstract}

\begin{abstract}
Клиничките испитувања покажаа дека хепарините со ниска молекуларна тежина се во најмала рака безбедни и ефикасни како нефракциониран хепарин за спречување на венски тромбоемболизам (ВТЕ) кај пациенти подложени на големи ортопедски операции, кои се со најголем ризик од развој на ВТЕ. Ретроспективната студија беше спроведена на ортопедското одделение во Клиничка болница - Штип за период од 12 месеци (јануаридекември 2013 година), каде што хепарините со мала молекулска тежина и нефракционираните хепарини се прифатени опции за тромбопрофилакса. 320 пациенти (144 мажи и 157 жени, средна возраст 58 години и 70 години, соодветно) биле хоспитализирани за разни видови на големи ортопедски хируршки интервенции. 212 $(66 \%)$ пациенти биле примени поради фрактури на колк или колено, $26(8 \%)$ имале состојби по фрактури на колк или колено, а 82 (26\%) биле хоспитализирани за отстранување или вградување на остеосинтетски помагала. По извршената хируршка интервенција, пациентите беа подложени на антикоагулантна профилакса со нефракциониран хепарин или хепарини со мала молекулска тежина. Изборот на видот на тромбопрофилаксата зависел исклучиво од одлуката на операторот. ВТЕ компликации кои резултирале со смрт биле забележани кај 8 (2,5\%) од 13 пациенти. Смртта поради пулмонална емболија (ПЕ) се случила кај 2 (25\%) од 8 пациенти, споредено co 6 (75\%) пациенти кои имале фатални компликации од далабока венска тромбоза (ДВТ). Просечните болнички трошоци за пациентите третирани со профилакса со хепарини со мала молекулска тежина како опција за прва линија на тромбопрофилакса изнесуваa 52831,92 денари/пациент во споредба со 70082,24 денари/пациент за опција за прва линија на тромбопрофилакса со нефракционирани хепарини. Ние забележавме дека тромбопрофилаксата со хепарини со мала молекулска тежина, применета во препорачаните дози субкутано еднаш дневно, е потенцијално поефикасна и економси поисплатива опција во споредба со нефракционираниот хепарин и треба да се смета како прв избор на фармаколошки третман за спречување на ВТЕ (ДВТ и ПЕ) кај пациенти кои се опоравуваат од голема операција на ортопедското одделение во Клиничката болница Штип.
\end{abstract}

